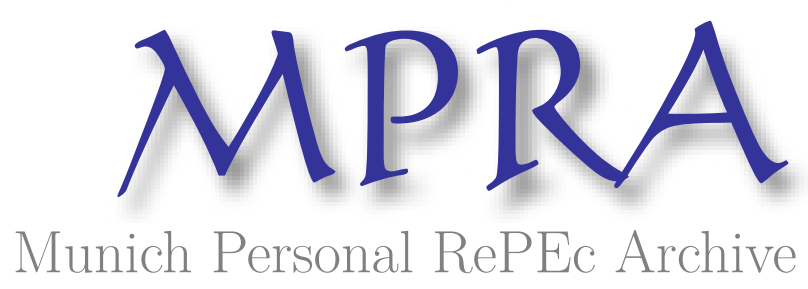

\title{
The Philippines in the Asian Financial Crisis: How the Sick Man Avoided Pneumonia
}

\author{
Noland, Marcus \\ Peterson Institute for International Economics
}

May 2000

Online at https://mpra.ub.uni-muenchen.de/55665/

MPRA Paper No. 55665, posted 02 May 2014 07:07 UTC 


\title{
The Philippines in the Asian Financial Crisis: How the Sick Man Avoided Pneumonia
}

\author{
Marcus Noland \\ May-June 2000 \\ I would like to thank Hye Kyung Lee for useful research assistance, and John \\ Williamson for helpful comments on an earlier draft.
}

For most of the last three decades, economic growth in the Philippines lagged its Asian neighbors, earning it such sobriquets as "the Sick Man of Asia" and "the Latin American of Asia." During the Asian financial crisis however, the sick man proved more resilient than his neighbors. This was not simply a matter of being unable to fall out of the basement. On the eve of the crisis in mid-1997, the Philippines economy was forecasted by the International Monetary Fund (IMF) and private sector analysts to grow at more than six percent in 1998 - a rate faster than most other low income countries worldwide, and a rate faster than the Philippines' own performance in recent history. When the crisis hit in the second half of 1997, those same forecasts exhibited less downward revision for the Philippines than for the other Asian countries, and in fact, the Philippines' contraction was considerably less severe than the others.

The question naturally arises as to why the Philippines, with its reputation for weakness, fared better in the crisis than other countries in the region. To answer that question one has to have a theory or explanation of the crisis, and then show how the Philippines differed from its comparators in the relevant dimensions. This paper examines two nonmutually exclusive explanations for the crisis, weak domestic fundamentals and international contagion, and concludes that the Philippines endured the crisis relatively more successfully than its neighbors both because its financial system was in better shape than others around the region, and because it had a uniquely low vulnerability to contagion. In particular, the Philippines had already had its financial crises, and as a consequence, had undertaken measures to strengthen its domestic financial system. This observation is at once both trite and profound: it suggests that backsliding on the part of the Philippines could lead to renewed problems, and, that with respect to the benefits of financial market reform, the other countries around the world might have something to learn from the sick man.

\section{The Fundamentalist Creed}

There are two principal economic theories or explanations for the Asian financial crisis: one which emphasizes the weakness of economic fundamentals, especially in the financial sector, and the other that emphasizes panic or international contagion on the part of financial market investors. ${ }^{1}$ The relevant "fundamentals" relate both to internal and external factors such as international trade competitiveness. ${ }^{2}$ Working from large global data bases on the financial crises, empirical research by Tornell (1999) and 
Goldstein et al. (2000) identify a fairly robust set of predictors of banking or currency crises which include rapid real exchange rate appreciation over trend; decline in equity prices; decline in export revenues; a high ratio of the domestic money stock to foreign exchange reserves, lending booms, decline in output, and a large current account deficit relative to national income or investment.

How did the Philippines stack up in 1997? Not too well on these measures. The Philippines began experiencing a nominal exchange rate appreciation in 1992 after the foreign exchange market was liberalized, and eventually the central bank would undertake a variety of measures including relaxation of capital outflow restrictions, repaying some foreign debts at an accelerated rate, and sterilized interventions in the currency market in an attempt to limit the appreciation. $\frac{3}{\text { These }}$ actions in turn encouraged the growth of the domestic money supply relative to foreign exchange reserves-another indicator of incipient financial crisis. The associated real exchange rate appreciation contributed to a modest slowdown in Philippine export revenues, though it is hard to disentangle how much of this was due to reduced export volumes and how much was due to falling prices. ${ }^{4}$ The Philippines did experience some mild adverse terms of trade shocks in the period before the crisis in the form of reduced prices for electronics exports and a variety of commodity exports. The current account deficit widened from less than two percent of gross domestic product (GDP) in 1992, to between four and five percent of GDP thereafter, despite a significant growth in revenues from remittances. The merchandise trade deficit exhibited an even more dramatic increase than the broader current account measure.

With regard to its internal fundamentals, the Philippines experienced an enormous lending boom in the 1990s. Bank lending to the private sector as a share of GDP more than doubled between 1990 and 1997. The stock market peaked in January 1997 and proceeded to fall by nearly 25 percent over the next six months. By most of the robust predictors of financial crisis, the Philippines was an accident waiting to happen. Indeed, Goldstein et al. (2000) report an experiment in which they use an econometric model to predict the out of sample vulnerability of 19 countries to financial crises. On the basis of the indicators for the period January 1996 to January 1997, the five countries most likely to experience a crisis were South Africa, the Czech Republic, Thailand, South Korea, and the Philippines. All except South Africa subsequently did experience crises. For the more inclusive period of January 1996 to December 1997, their model identifies the countries most likely to experience a crisis as being the Czech Republic, South Korea, Thailand, South Africa, and Colombia. Again, South Africa was the only one which did not experience a crisis. The surprise is not that the Asian countries, including the Philippines, experienced crises-it was that South Africa did not. The bottomline is that the Philippines crisis could have been predicted on the basis of weak fundamentals.

\section{Crisis Performance}

Yet as can be seen in table 1, the deviation between the Philippines forecast growth rate in 1998 and its actual performance was by far the smallest of the Asian countries. This was not simply a matter of luck: the forecast revisions were also the smallest, 
indicating that the forecasters believed that the Philippines was likely to be the least affected of the Asian countries. There are essentially two explanations: first, that the Philippines financial sector was stronger than others around the region, and second, that the Philippines was uniquely insulated from regional contagion.

Historically, the Philippines had a relatively repressed and inefficient financial system. Williamson and Mahar (1998) survey the financial systems of 34 countries, rating them on six dimensions: credit controls, interest rates, entry barriers, bank autonomy, privatization, and international capital flows. In each case the Philippines banking sector of the 1970s received a grade of "repressed" or "partly repressed." Hutchcroft (1998) describes the Philippine banking sector as characterized by "rampant favoritism" and "inefficient state regulation." (This is, afterall, the country that gave us the term "crony capitalism."

As a consequence, the Philippine financial sector did a poor job of mobilizing saving and allocating capital, and was prone to instability, experiencing crises in the mid-

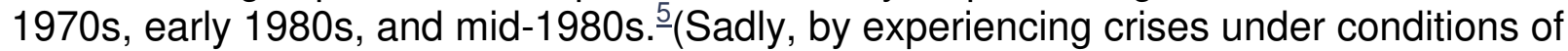
both capital account openness and closure, the Philippines proved that "hot money" international capital flows may be a sufficient, though are not a necessary, condition for financial meltdown.) The formal banking sector was essentially an urban phenomenon-in the rural areas wealth was predominately held in non-monetary forms. Barriers to entry and regulatory forbearance contributed to cartelization of the banking sector and the consequent super-normal profits to those lucky enough to obtain a banking license.

The Philippine government undertook a number of significant reforms of the real side of the economy in the 1980s, equalizing incentives across different activities, a process that continued into the 1990s. There had been a number of attempts to change the financial system, but it was not until the 1990s, that significant reform was achieved. Initially, entry barriers were modestly relaxed, with the number of branches increasing from 1,957 at the end of 1990, to 3,175 at the end of 1995 (Fritz-Krockrow, 1999). This was followed by a period of reform during 1993-5 in which the central bank was rehabilitated, commercial banks were forced to increase their capitalization ratios, new foreign and domestic entrants were allowed to enter the market, and the quality of prudential regulation was strengthened. The result was an increase in competition that eroded some oligopoly profits, promoted the mobilization of saving, and encouraged financial deepening. So, for example, the ratio of money and quasi-money to national income, which had been rising steadily since 1986 accelerated its increase, more than doubling from 23 percent to 49 percent between 1986 and 1996.

Not only was the amount of finance increasing, so was its quality. As noted earlier, reforms begun in the 1980s had significantly equalized incentives across activities. The financial sector reforms which opened the banking system to new domestic and foreign entrants contributed to a managerial and technological upgrading of the system, in part driven by a reverse brain drain of returning Filipino bankers who had been employed 
outside the Philippines by foreign banks. Together, these reforms combined generate a more efficient pattern of investment.

Table 2 reports changes in the incremental capital-output ratio, an admittedly crude indicator of the efficiency of investment. As countries develop, capital deepening occurs, and one would expect the incremental capital output ratio to rise (i.e. as more capitalintensive techniques of production are adopted, the amount of investment needed to produce a unit of output increases). Instead, the data for the Philippines shows a fall in the incremental capital-output ratio. That is to say, the Philippines was getting significantly more "bang for the buck" in the mid-1990s than it had a decade earlier.

Indeed, on a variety of financial market indicators, on the eve of the crisis, the Philippine financial system looked more solid than did others in Asia (tables 3 and 4). Although the Philippines experienced a domestic credit boom in the mid-1990s, it went on for a shorter duration than those else where in Asia. So, for example, the Philippine banking sector appears to have been less "over-lent" than others in Asia on the eve of the crisis in aggregate terms. Moreover, the quality of bank lending appears to have been higher as well: exposure to the real estate sector was lower, collateral valuations were lower, and capital adequacy was higher. Non-performing loans were lower going into the crisis, and increased less once the crisis was underway. This is not to say that the Philippine financial sector was perfect: as Williamson and Mahar (1998) observe, despite the abolition of directed credit, commercial banks remained dependent on the central bank's discount window providing a mechanism for the government to influence lending, and cartel price-fixing practices had not been eradicated, despite new entries into the market. Nor have subsequent events demonstrated that the financial system is free of taint. Rather, this is only to say that the Philippine system looked good relative to those elsewhere in Asia.

The lower real estate exposure, in particular, turned out to be important. ${ }^{-}$As Hutchcroft (1999) points out, because of higher interest rates prevailing in the Philippines, property developers were forced to adopt more conservative approaches to financing, and were less over-leveraged than their Thai counterparts. This was reinforced in June 1997 when the central bank imposed ceilings on banks' loan exposure to the real estate sector and the permissible collateral valuation of real estate security. ${ }^{\underline{7}}$ As a consequence, the Philippines (and South Korea) were distinct in that to a significant extent the domestic lending boom financed overcapacity in internationally traded-goods sectors, rather than non-tradables such as real estate. Moreover, the Philippine corporate sector was less over-leveraged than elsewhere in Asia (table 5).

This difference in the sectoral pattern of lending had implications for how the economy was able to respond to the crisis. When the exchange rate collapsed the country experienced a significant real exchange rate depreciation, as did other countries in Southeast Asia. However, to greater extent that the others, the lending boom in the Philippines had financed investment in internationally tradable sectors. Because of excess capacity in the tradables sector and less impairment of corporate balance sheets meant the Philippines was better able to exploit the real exchange rate 
depreciation, increasing exports (as well as substituting domestically produced goods for imports). As a consequence, the Philippines was able to generate the big reduction in its current account deficit through exporting (and thereby maintaining the level of domestic output), rather than through a compression of imports. ${ }^{-}$

Yet fundamentals are only half of the story. What about contagion? There are essentially two channels. One is through international trade. If one country devalues then other countries which compete against it in world markets have been relatively disadvantaged (i.e. they have experienced a real exchange rate appreciation). It is not necessary that the countries compete against each other in each others' markets-in fact, the competition is likely to occur in third country markets. So, for example, when Thailand devalued the baht, Philippine exporters were disadvantaged in the US and Japanese markets. Thus a devaluation by one country can lead to pressure for competitive devaluations by other, similarly situated, countries.

The second channel is through the financial markets. There is a growing academic literature that seeks to provide theoretical explanations of herd-like behavior on the part of investors. ${ }^{-}$The empirical evidence on the determinants of contagion is conflicting: Glick and Rose (1998) find that trade links do a better job than herding in explaining contagion, while Choe, Kho, and Stulz (1999) and Kim and Wei (1999) provide evidence to suggest that prior to the crisis, foreign investors tended to be herding, positive feedback traders.

With respect to the trade channel, Noland et al. (1999) show that the devaluations elsewhere in Southeast Asia had only a modest impact on the Philippines balance of payments position. Moreover, the Philippines appeared to have been less vulnerable to financial market contagion than its neighbors for reasons of both policy and luck. Because of the Philippines experience during the debt crisis of the 1980s, its policy makers appeared to be particularly risk-averse, especially with regard to short-term fixed interest rate bank debt. $\stackrel{10}{-1}$ At the onset of the crisis, Philippine debt indicators were better than its neighbors (table 5). In particular, compared to its neighbors, the Philippines had relatively less exposure to Japanese bank lending. This was due both to low levels of Japanese foreign direct investment in the Philippines relative to other Southeast Asian countries (Japanese banks tended to follow their domestic clients into foreign countries) and policies which had encouraged non-Japanese banks into the Philippine market. The presence of non-Japanese banks and their competitive advantages over Japanese banks tended to crowd-out Japanese lending to nonJapanese borrowers. This would become important in the fall of 1997, when the weakness of Japanese banks caused them to begin refusing to roll-over loans, and even calling in existing loans. ${ }^{11}$

At the same time, due to the country's historically weak economic performance relative to its neighbors, despite its relatively developed and open capital markets, it was underweighted in the Morgan Stanley Capital International (MSCl) Far East Ex-Japan Free Index, the benchmark against which the performance of mutual funds investing in

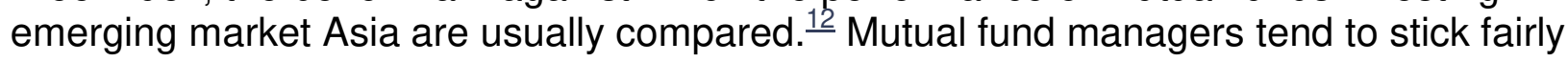


closely to the index in their country allocations, so as a consequence, the Philippines had relatively less exposure to foreign mutual fund managers. Again, this meant that the Philippines had relatively less exposure to international "hot money" flows than did others in the region.

Goldstein et al. (2000) use an econometric model to attempt to integrate quantitatively the two basic contributing factors to the occurrence of a financial crisis: weak fundamentals and contagion. They find that while the dominant cause of the financial crisis in Indonesia was contagion, it played virtually no role in the Philippines (table 6). The Philippine crisis was almost entirely home grown.

\section{Conclusions}

The Philippines has long been regarded as the weak sister of Asia, but in the Asian financial crisis it performed relatively well. This is not simply a matter of not being able to fall out of the basement, either-in mid-1997 the Philippines economy was forecasted to grow at more than six percent in 1998, and both the post-crisis forecasts revisions, and the degree of the eventual contraction were less in the Philippines than elsewhere in Asia. Rather, the Philippines crisis experience offers valuable lessons for the Philippines, the rest of Asia, and indeed, emerging markets around the world. The lesson is that policies matter: economic reform, particularly of the financial system, can have a demonstrable impact on a country's ability to weather a crisis, even if the crisis originates elsewhere and is spread by contagion.

This is not to say that the Philippines is a model of economic rectitude. It is not, and the evidence presented in this paper suggests that despite a decade of reforms, the crisis that hit the Philippines in July 1997 was largely home grown. (Indeed, the home grown crisis might have been worse had not external events short-circuited the domestic lending boom which was underway.) Worse yet, since the crisis the country has failed to capitalize on its relatively strong performance. It has experienced several financial scandals and key pieces of economic reform legislation have languished in the Congress for months.

Nevertheless, the sick man merely caught a cold-he did not catch pneumonia. Had the Philippines not undertaken its financial sector reforms, the crisis undoubtedly would have been worse. Moreover, backsliding could precipitate a crisis in the future. These are lessons that policy makers both inside and outside the Philippines should take to heart. Afterall, if the sick man can avoid pneumonia, so can you.

\section{Table 1: Real GDP Forecasts and Growth}

IMF Forecast Private IMF Forecast Private Real GDP




$\begin{array}{ccccc}\text { for 1998 } & \text { Consensus } & \text { Revision (May } & \text { Consensus } & \text { Growth } \\ \text { (May 1997) } & \text { Forecast for } & \text { 1997-May } & \text { Forecast } & 1998 \\ & \text { 1998 (June } & \text { 1998) } & \text { Revision (June } \\ & 1997) & & \text { 1997-June } \\ & & & \text { 1998) }\end{array}$

\begin{tabular}{|c|c|c|c|c|c|}
\hline Indonesia & 7.5 & 7.5 & -12.5 & -12.5 & -13.1 \\
\hline Korea & 6.3 & 6.2 & -7.1 & -9.2 & -5.8 \\
\hline Malaysia & 7.9 & 8.5 & -5.4 & -7.5 & -6.7 \\
\hline Thailand & 7.0 & 6.5 & -10.1 & -11.0 & -7.8 \\
\hline $\begin{array}{l}\text { The } \\
\text { Philippines }\end{array}$ & 6.4 & 6.1 & -3.9 & -4.0 & -0.5 \\
\hline
\end{tabular}

Sources: IMF, World Economic Outlook Interim Assessment, December 1997;

IMF, World Economic Outlook, May 1998;

FT Currency Forecaster, June 1997, June 1998.

\section{Table 2: Banking System Exposure to Risk}

\begin{tabular}{|c|c|c|c|}
\hline & $\begin{array}{c}\text { Short-term } \\
\text { debt/Total debt }\end{array}$ & $\begin{array}{c}\text { Short-term } \\
\text { debt/Reserves }\end{array}$ & $\begin{array}{l}\text { Ratio of } \\
\text { corporate debt to } \\
\text { equity, } 1997\end{array}$ \\
\hline Indonesia & 24 & 160 & 2.3 \\
\hline Korea & 67 & 300 & 6.4 \\
\hline Malaysia & 39 & 55 & 2.2 \\
\hline Thailand & 46 & 107 & 4.1 \\
\hline The Philippines & 19 & 66 & 1.9 \\
\hline
\end{tabular}

Note: Data for the first column is as a percentage of GDP. Data for the last five columns are as a percentage of assets at the end of 1997.

Sources: Data are from JP Morgan, Asia Financial Markets, January 1998 and Corsetti et al (1999, table 19).

\section{Table 3: Central Business District Office Vacancy Rates and Rental Yields}




\begin{tabular}{lcccc} 
& \multicolumn{2}{c}{ Vacancy Rates } & & Rental Yields \\
\cline { 2 - 3 } & $1997(\%)$ & $1998-99(\%)$ & & June $1997(\%)$ \\
Bangkok & 15.0 & 20.0 & 6.80 \\
Jakarta & 10.0 & 20.0 & 7.20 \\
Kuala Lumpur & 3.0 & 20.0 & 8.80 \\
Manila & 1.0 & 3.0 & 9.30 \\
\hline
\end{tabular}

Source: Corsetti et al. (1999), Table 9.

Table 4: Change in Incremental Capital-Output Ratio, 1987-1996 (percentage points)

\begin{tabular}{lr} 
Indonesia & -0.2 \\
Korea & 1.1 \\
Malaysia & 1.1 \\
Thailand & 1.7 \\
The Philippines & -0.5 \\
\hline
\end{tabular}

Source: IMF, International Financial Statistics, Various issues.

Table 5: Financial Indicators

\begin{tabular}{lcccc}
\hline & $\begin{array}{c}\text { Short-term } \\
\text { debt/Total debt }\end{array}$ & & $\begin{array}{c}\text { Short-term } \\
\text { debt/Reserves }\end{array}$ & $\begin{array}{c}\text { Ratio of } \\
\text { corporate debt to } \\
\text { equity, 1997 }\end{array}$ \\
\cline { 2 - 3 } Indonesia & 24 & & 160 & 2.3 \\
Korea & 67 & 300 & 6.4 \\
Malaysia & 39 & 55 & 2.2
\end{tabular}


Table 6: Marginal Increase in Crisis Probability Due to Common External Lenders

$\begin{array}{ll}\text { Indonesia } & 0.60 \\ \text { Malaysia } & 0.35 \\ \text { The Philippines } & 0.02\end{array}$

Source: Goldstein et al. (2000), Table 6.3.

\section{References}

Bautista, Romeo M, and Mario M Lamberte. 1996. "The Philippines: Economic Developments and Prospects," Asian-Pacific Economic Literature 10:2 (November) 1631.

Barth, Marvin and Trevor Dinmore. 1999. "Trade Prices and Volumes in East Asia Through the Crisis," International Finance Discussion Papers Number 643, Washington: Board of Governors of the Federal Reserve System (August).

Calvo, Guillermo A. and Enrique G. Mendoza. 2000. "Rational Herd Behavior and the Globalization of Securities Markets," Journal of International Economics, forthcoming.

Choe, Hyuk, Bong-Chan Kho, and René Stulz. 1999. "Do Foreign Investors Destabilize Stock Markets?," January, processed.

Corsetti, Giancarlo, Paolo Pesenti, and Nouriel Roubini. 1999. "What Caused the Asian Currency and Financial Crisis?," Japan and the World Economy 11:3 305-73.

Drazen, Allan. 1997. "Contagious Currency Crises" College Park: Center for International Economics, University of Maryland, processed.

Estanislao, Jesus P. 1997. "The Philippine Economy: An Emerging Asian Tiger," Asia \& Pacific Lecture Series, no. 1. Singapore: Institute of Southeast Asian Studies. 
Fritz-Krockrow, Bernhard. 1999. "Saving and Financial Intermediation in the Philippines," EXIM Review19:2 (July) 88-110.

Glick, Reuven and Andrew Rose. 1998. "Contagion and Trade," NBER Working Paper Series 6806.Cambridge: National Bureau of Economic Research.

Goldstein, Morris, Carmen Reinhart, and Graciela Kaminsky. 2000. Assessing Financial Vulnerability: An Early Warning System for Emerging Markets. Washington: Institute for International Economics, forthcoming.

Hutchcroft, Paul D. 1998. Booty Capitalism: The Politics of Banking in the Philippines. Ithaca: Cornell University Press.

Hutchcroft, Paul D. 1999. "Neither Dynamo nor Domino: Reforms and Crises in the Philippine Political Economy," in T.J. Pempel editor, The Politics of the Asian Economic Crisis. Ithaca: Cornell University Press.

Kim, Woochan, and Shang-Jin Wei. 1999. "Foreign Portfolio Investors Before and During A Crisis,"NBER Working Paper Series 6968. Cambridge: National Bureau of Economic Research.

Krugman, Paul R. 1997. "Currency Crises," Cambridge: Department of Economics, MIT, processed.

Noland, Marcus, Li-Gang Liu, Sherman Robinson, and Zhi Wang. 1999. Global Economic Effects of the Asian Currency Devaluations (revised). Washington: Institute for International Economics.

Tornell, Aaron. 1999. "Common Fundamentals in the Tequila and Asian Crises," NBER Working Paper Series 7139. Cambridge: National Bureau of Economic Research.

Williamson, John and Molly Mahar. 1998. "A Survey of Financial Liberalization," Essays in International Finance No. 211, International Finance Section, Department of Economics, Princeton University, November.

\section{Notes}

See Noland et al. (1999) for a more detailed discussion of these theories and literature references. In some models the panicked investors would not necessarily be foreign investors-domestic capital flight could be another source of large rapid international capital movements.

2. The principle, one could further try to separate "internal" and "external" sources of fundamental strength or weakness. However in practice they are typically interrelated: 
for example, real exchange rate overvaluation often leads to lending booms in domestic non-tradables such as real estate. For a useful synopsis of Philippine economic policy in the period immediately preceding the crisis, see Bautista and Lamberte (1996). See Barth and Dinmore (1999) on this point.

3. For a useful synopsis of Philippine economic policy in the period immediately preceding the crisis, see Bautista and Lamberte (1996).

4. See Barth and Dinmore (1999) on this point.

5. Fritz-Krockrow (1999) argues that more general macroeconomic instability (particularly high and variable inflation) discouraged saving and hampered financial intermediation, especially the development of long-term financial instruments.

6. In this regard, the prescient response by former finance minister Jesus $P$. Estanislao (1997) to a question posed at a 15 May 1997 lecture bears repeating: "In the case of Thailand, two critical sectors have been weakened because of over-capacity: real estate and banking. Real estate suffers from over-capacity: too many units have been built in relation to actual and potential demand. The financial sector, which was over-extended to the real estate sector, suffers from a high rate of past due loans in their overall loan portfolio. In the Philippines, the real estate sector is far from being overbuilt. The occupancy rate in prime commercial areas is very high, at more than $95 \%$, and real estate as a sector accounts for less than $15 \%$ of the loan portfolio of the banking system. In fact, based on all the information available, both confidential and nonconfidential, the Philippines banking system is solid (p.28)."

7. These restrictions were tightened immediately upon the commencement of the crisis in July 1997. At the same time the central bank imposed new liquidity requirements on foreign currency liabilities and removed tax disincentives on peso deposits.

8. In this regard, the Philippines also benefitted from continued inflows of worker remittances.

9. See, for example, Drazen (1997), Krugman (1997), and Calvo and Mendoza (2000).

10. Again, it is worth quoting Estanislao's (1997) pre-crisis statement on this point: "Having been burned by the foreign debt problem of the 1980s, we in the Philippines are taking a very conservative stance toward foreign financing. We go for long-term bonds, and where possible also for equity finance from abroad. That is why we have been very active in the bond market as well as the equity market. We are so much less reliant on short-term commercial bank funding, from which we have been shying away" (p.35)

11. Japanese banks reduced their exposure to the rest of Asia by an estimated $\$ 30$ billion in 1998, accounting for roughly 30 percent of the net capital outflow the region experienced in 1998. By 1999 nearly half of the Japanese banks which had been operating in Asia in mid-1997 had pulled out. 
12. At the time of the crisis, the Philippines was the only large Southeast Asian economy under an IMF program, which may have acted as a crude signal for foreign investors to proceed with caution, despite the notion that an agreement with the IMF is sometimes regarded as something akin to a macroeconomic "Good Housekeeping Seal of Approval." 